\title{
Strengthen the Integrity Education of University Students and Promote the College Ideological and Political Education
}

\author{
L. LIN \& M.G. LI \\ Engineering Research Center of Metallurgical Automation and Measurement Technology, Ministry of \\ Education, Wuhan University of Science and Technology, Wuhan 430081, China
}

\begin{abstract}
The eighteen Party Congress puts forward strengthen anti-corruption education and the construction of a clean government culture, puts forward new tasks and new requirements to strengthen the cultural construction of honest and clean government. In this new inclination, it has been an important theme in contemporary task about how the workers of ideological and political education capture the critical point acting on integrity education of university students specifically and promoting the ideological and political education of university students in accordance with actual condition in each university.
\end{abstract}

KEYWORD: integrity education of University Students; Ideological and political education; university education

\section{INTRODUCTION}

The eighteen Party Congress puts forward "strengthen anti-corruption education and the construction of a clean government culture", puts forward new tasks and new requirements to strengthen the cultural construction of honest and clean government. In the new situation, how to grasp the focus of work, combining the reality of the University in a targeted manner to promote the construction of a clean government culture, is an important topic in the work. In recent years, especially in the study and implement the spirit of the party's eighteen activities, integrity education of university students is the focus of attention of the problem. Honesty education for college students, is refers to the teacher, with the honest government culture theory, influencing with purpose, plan on college students, making students constantly improve the moral self-discipline consciousness, enhancing the good psychological quality of corruption, and gradually forming a clean fingered self-discipline, dedication etc[1]. Incorruptible education for college students is already formed consensus. In 2003 October, the fifty-eighth session of the general assembly publish the "United Nations Anti-corruption Convention", which includes "the honesty education as school and university curricula, public education". In 2005 January, the Central Committee of the Communist Party of China promulgated the "establishment of a sound education, system, supervision of both punishment and prevention of corruption Implementation Outline", put forward the honest education as an important content of the ideological and moral education of teenagers. To implement the document requirements, in 2005 July the Ministry of Education issued "about carrying out the pilot work on honesty education of middle and Primary School of opinion", making the honesty education in middle schools spread as soon as possible[2]; in 2007 March the Ministry of Education promulgated "on the full implementation of clean Education opinion" in middle and primary school; 2010 "on strengthening the cultural construction of honest and clean government opinions" further requirements, is based on the present, focusing on the long term, focus, promoting the overall, continuing to deepen the education of young people and building work. Honesty education can not be separated from the ideological and political education system, but should be permeated in Ideological and political education and students' daily education and management, and make a clean education close to reality, close to life, close to the students. Ideological and political education of college and university students' honesty education both in theoretical dimension, in the bearing of content, and in the rule are mutually fit. Do a good job of the honesty education of the university students, promotes efficient development of powerful ideological and political work in Colleges and universities[3]. 


\section{THE BASIC CONNOTATION OF THE EDUCATION OF HONESTY}

Honesty is a moral and clear person, who should have, and who should comply with the provisions of the laws, the party organization and the social and moral requirements, not using its power and duty to seek illegal and illegitimate interests. Honesty education for college students is to build a harmonious campus, promoting an important link of the social harmony. Strengthening the integrity education for college students is a long-term, strategic project based on the society. On the long run, now college students are the backbone of the future society, the successors of the socialist cause, and the reserve army. In key stage of formation values how they thought consciousness has at present, immediately influence that they will take what kind of force way of the future. Whether they have a clean consciousness and behavior, is bound to affect whether our country can maintain sustained, stable development, and has the future of farreaching influence for social harmony[4]. In reality, some college students are infected with bad social ethos, appearing "dinner party votes", "seek nothing but profits, the supremacy of money", abuse of power in the hands of the "official standard" the serious phenomenon. And some student organizations are gradually alienated, and even become the evil practices. Unwholesome tendencies and corruption, coupled with a large number of western culture, values and behavior, the wrong thought seriously, cause some students of different level land exists confused political beliefs, honesty and faith, value orientation and moral fuzzy split personality problem. But honesty education of college students in Ideological and political education aims at university's existing and innovative way of education, letting the students gradually establish honest awareness, establish correct world outlook, outlook on life, values and power, and finally letting students get all-round development and make contribution to the harmonious society. Honesty education of college students, not only has the "anti-corruption education", also includes honesty, law-abiding, loving, dedicated content.

\section{THE SIGNIFICANCE OF STRENGTHENING COLLEGE STUDENTS' HONESTY EDUCATION}

College students are the future and hope of the country, a reserve force of high-quality talent, the cause of the party and the country's successor. Their comprehensive quality related to the success or failure of the socialist cause. While the basic attitude of college students to honesty problem, but also determines our future social basis of honest construction. Therefore, carrying out and having importance to strengthen the honesty education of College students is important.

\subsection{To carry out integrity education of university students is an important way to strengthen the ideological and political education of College Students}

College students are in the key period of the growth thought, and the education will be directly related to their growth and development. Under the market economy condition, some people cannot live in pluralistic culture and values of the impact, susceptible to hedonism, mammonism, individualism and other effects of decadent ideas, vulnerable to improper benefits temptation, resulting in corruption. Therefore, developing the honesty education in this period, helps students to establish correct world outlook, outlook on life, values and outlook for honor and dishonor, and cultivates noble moral sentiment; to promote college students strengthening self-discipline consciousness, responsibility consciousness, legal consciousness and sense of integrity; to help students improve the ability to distinguish right from wrong, to conscientiously resist erosion of decadent ideas ideological and moral, building a strong line of defense against.

\subsection{To carry out integrity education of university students is the inherent requirement of helping students all-round development}

College students are in the world outlook, outlook on life and values to the key stage of maturity, at this stage by the targeted education. Cultivating their sense of integrity, will be a solid foundation for the development of their lives lay. In the system the honest education content to strengthen the honesty education of them, providing them for advance "anticorruption" vaccine inoculation, leading them to set up to serve the motherland, serve the people of faith, improving their moral self-discipline consciousness, enhancing the good psychological quality to resist corruption change, gradually forming the professional concept of honesty and self-discipline, dedication, to ensure the growth into mainstream social health and strength, which is the inherent requirement of College Students' self-realization.

\subsection{To carry out integrity education of university students is an important basis for building a harmonious socialist society}

The people are the basic elements of a harmonious society, a good guide of social individuals, honesty and self-discipline, social groups, the harmonious 
coexistence of society, which is the basic characteristic of a harmonious society. Growth of students is an important foundation for the building of a harmonious society. Developing and strengthening the integrity education for college students, guiding students to correctly understand in real life and processing of individual and others, individual and collective, personal and social relations, are important the formation of honest pride, greedy disgrace of social morality, and the formation of new interpersonal relationship of solidarity, equality and common progress, promote social stability harmony[5].

\section{THE CURRENT STATUS OF COLLEGE STUDENTS HONESTY EDUCATION}

The honest education into the school, teaching materials, classroom and the mind is a general requirement of current university clean and honest culture activities. Colleges and universities through the main channel of Ideological and political education carry out extensive as the leadership, take the student as the main body of education activities to teachers, and incorruptible education through various channels, to enable students to establish honest consciousness and concept in the influence character by environment in.

\subsection{The form of education, content is relatively single and traditional}

At present the education of college students honesty is mainly traditional form of education through the "big classes, report, typical tree", failed to timely, innovative education mode and enrich the education content automatically according to the new situation, networking, internationalization of the development of the society, the relative neglect of network new media education communication effect.

\subsection{The lack of pertinence, honesty education system}

The theme of the clean and honest culture education in many universities is lack of further refinement, further subdivision of the education of university subjects, such as the student cadre group, student group of Party members and senior groups in the process of education have different characteristics. Because of the lack of honesty education level subdivision, and it is difficult to form a mechanism of the education system of the clean and honest culture in Colleges and universities, as a mainstream culture guided and radiation function cannot be fully play. Honesty education for college students in Colleges and universities still in deep thought and emotion, subjective initiative and creativity.

\subsection{The clean and honest culture activities effect to be enhanced}

To enhance the actual effect of many colleges and universities in the development of the clean and honest culture activity: some activities tend to pursue the activity scale, on the activities of the effectiveness of the lack of prediction, ignore the activity targeted content; some activities not wide coverage, limited to the part of the students to actively participate in the activities, has not yet formed a mechanism for most or all of the students generally participate in activities and to receive education[1].

\section{THE WAYS OF STRENGTHENING UNIVERSITY STUDENTS' HONESTY EDUCATION}

There are some following ways to improve our work methods. With these ways, we can strength students' honesty education and promote the ideological and political education.

\subsection{Build a long-term mechanism of university students 'honesty education}

We should establish the mechanism which are the unified leadership of Party committees, management of government and participation of teachers and students. So we can strengthen the honesty education for college students, keep the long-term existence of the honesty education of university students, and ensure the smooth development of honesty education of university students. Colleges should improve the construction of the system and establish the safeguard mechanism of college students' honesty education by the ways of improving policy, formulating system and standardizing management. The institutional constraints and standardized management can make teachers and students create an impartial and incorruptible healthier environment. What's more, we should establish specialized mechanism of the supervision and evaluation, which can improve the timeliness of honesty education and guide students to arouse their enthusiasm[4].

\subsection{Innovate the forms of college students' honesty education}

We should respect students' subject status, grasp the current college students' interest characteristics, expand the forms of situational education, experience education, enhance the effect of the education. To preserve the role of education carriers and the propagation paths of new media micro-blog, micro-film, we should pay attention to guiding, educating positively, and arousing students' subjective initiative and educational consciousness. 


\subsection{Pay attention to the classification of education and teach students in accordance with their aptitude}

Refine the theme of the clean and honest culture education into several specific sub topic to conduct the research. According to difference between different groups of a cadre of students, party members of students, high and low grade students, we select modes of education. According to the different disciplines of students, combined with the industry characteristics of their future occupation career planning, we plan the anti-corruption education content and increase the attraction and appeal of education[1].

\subsection{Create the brand activities of university students' honesty education}

We should strive to carry out the practical theme activities, which are love to see and hear, and easy for college students to participate in. Furthermore, we can expand the coverage of honest culture activities, guide students to participate universally in, strengthen moral consciousness and develop good habits. And we can establish the student-honest files as the carrier, strengthen the honest awareness of self-discipline and heteronomy, and resist the negative effects of the lack of honesty, resorting to deceit, academic misconduct and other negative factors. Taking the university career planning, occupation career planning as the carrier, we can carry out the clean and honest culture activities with professional characteristics. To build the honesty education brand activities and expand the clean and honest culture practice carrier, we will take college students' honesty education activities into the construction of campus culture, and create the iconic brand activities, which embody the clean and honest culture concept and guide cultural construction of clean image[1].

\section{CONCLUSION}

Honesty education of university students is a systematic project, which is currently facing. Doing a good job of incorrupt education for university students will greatly promote the ideological and political education work, and make due contribution to the construction of a harmonious society in China, and create a clean social environment.

\section{REFERENCES}

[1] Huang Jiqing. Discussion on the work of the Communist Youth League in College Students Honesty Education in the role of the University forum, May, 2011.

[2] The CPC Central Committee and State Council. Suggestions on further reinforcement and improvement of Ideological and moral construction of minors, Feb, 2004.

[3] The Ministry of education of the people's Republic of China. On the full implementation of clean education views in the middle and primary school, Mar, 2007.

[4] Chen Kee. Study on the construction of College Students' honesty education model, Journal of Hubei Institute of science and Technology (HUMANITIES AND SOCIAL SCIENCES EDITION), May, 2013.

[5] Xia Hanhui. To do the College students' honesty education, culture social qualified personnel, Journal of Guangzhou Institute of navigation, Jun, 2013. 